DOI: $10.17516 / 1997-1370-0678$

УДК 338.483.13(669)

\title{
Religiosity and Customer Experience: a Study of the Nigerian Hospitality Industry
}

\author{
Powel Maxwell Worimegbe* \\ Olabisi Onabanjo University \\ Ago-iwoye, Ogun, Nigeria
}

Received 21.07.2020, received in revised form 24.08.2020, accepted 12.11.2020

\begin{abstract}
The effect of religiosity on customer experience has engendered a lot of debate in the existing literature. This study examines the effect of religiosity on customer experience among the three major religious groups in the hospitality sector in Nigeria. The study is premised on the dimensions of religiosity, which are religious knowledge, orientation, commitment and affiliation. Employing the survey research design, 544 customers in the hospitality industry who cut across the three main religions in Nigeria were sampled. The study employed the PLS-SEM tool in the analysis of data. The PLSSEM analysis shows that religiosity ( $\mathrm{t}$-value $=134.668$ ) is a significant determinant of customer experience in the hospitality sector. The findings further reveal that there is no significant difference in customer experience among the three main ethnic groups in Nigeria. Practical Implication: It is inferred from the study that firms should pay attention to religiosity in order to give the customers an exciting experience. More attention should be paid to the customers' religious orientation and knowledge. The role and significance of religion as relating to religious, affiliation, commitment, orientation and knowledge of the customers should not be ignored by firms in the provision of goods and services which will bring about better service encounter.
\end{abstract}

Keywords: hospitality, religiosity, customer experience, service encounter.

Research area: economy.

Citation: Worimegbe, P.M. (2020). Religiosity and customers experience: a study of the Nigerian hospitality industry. J. Sib. Fed. Univ. Humanit. Soc. Sci., 13(11), 1723-1735. DOI: 10.17516/19971370-0678.

(C) Siberian Federal University. All rights reserved

* Corresponding author E-mail address: powelmaxwell@yahoo.com; buch 53@mail.ru 


\section{Introduction}

Customer experience is a multidimensional construct which seeks to address the emotions, perceptions, and behaviour of the customers before service encounter, during service offerings and after service delivery. Kuppelwieser and Klaus (2018) opine that customer experience is important in explaining consumers' emotions and cognitive responses. Stein and Ramasehan (2016) opine that it is not enough for firms to concentrate on generic offerings; customers now seek service encounter tailored towards personalised experience. This has made firms to differentiate their services from their rivals in the industry by offering and delivering more unique and personalized customer experience (Stein \& Ramaseshan, 2016; Lemon \& Verhoef, 2016). Customer experience is an aspect of customer behaviour which expresses the emotions and reactions of the customers while interacting with the firm and its products (Klaus and Maklan, 2013). Customer behaviour have been revealed to be influenced by many factors and in most recent times the role of culture and its sub-components such a religion (Mokhlis, 2009; Halliru, 2013)

The role of culture in consumer behaviour has been sufficiently looked into in the existing literature. Halliru (2013) opines that religion plays a pivotal role in influencing the taste and preference of consumers across different religious backgrounds. Abu-Alhaija, Yusof, Hashim and Jaharuddin (2018) posit that religion is not only a social construct but also a behaviour enhancer which has the capacity to induce either positive or negative emotions from the consumers. Abou-Youssef, Kortam, Abou-Aish, and El-Bassiouny, (2015) argue that religiosity (religious commitment) is a tool which should be explored in the marketing literature to determine the extent to which it can affect the behaviour of the consumer. However, Souiden and Rani (2015) stress that religiosity is a complex construct which is blurry. This is premised on the belief that religion is a personal experience and as such, how a religious person feels in the consumption of goods and services is relative depending on the person's religion and affiliation.
Several studies have revealed the extent to which the consumer behaviour could be affected (Mokhlis, 2009; Muhamad \& Mizerski, 2010; Abou-Youssef et al., 2015; Agarwala, Mishra \& Sing, 2018). While these studies show that religion is an important driver of consumer behaviour, the basis of measurement of religiosity as a construct has been a fundamental issue. Al Abdulrazak and Gbadamosi (2017) and Muhamad and Mizerski (2010) argue that religiosity is a multidimensional facet which measurement is divergent to different religions perception, orientation and beliefs that are unique for them. In order to overcome the issue of measuring the religiosity construct, Abu-Alhaija et al. (2018) suggest that study on religiosity as it affects customers' behaviour should be considered in the context of individual religion existing in a particular place. What is allowed in one religion could be forbidden in another (Mokhils, 2009) and could bring about different experiences to the customers. Choi (2010) and Essoo and Dibb (2004) opine that religiosity is a significant driver of customer risk perspective, shopping behaviour and lifestyle of the consumer. While all these studies examine the effect of religiosity on consumer behaviour in general, it is yet to be established in the extant literature how religiosity could influence customer experience. According to Mathras et al. (2016), most of the studies undertaken in religion and consumer research have been qualitative, and this creates a need to investigate the interaction between religiosity and consumer behaviour. Hence, this study seeks to examine the effect of religiosity on customer experience in Nigeria among the three religions (Christianity, Islam and traditional religion) and investigate if there is any significant difference in customer experience among the three religions. The study also addresses the issue of measurement of religiosity and seeks to establish the most significant construct of religiosity influencing customers experience in the hospitality industry in Nigeria. The choice of the hospitality was motivated by the opinion of Sibal (2018) who establishes that the hospitality industry is significant in the contemporary society, dynamic and it could be complex due to the in- 
fluence of culture and religious beliefs which is divergent.

\section{Literature Review \\ Concept of Religiosity and Measurement}

The concept of religiosity and its measurements have been extensively discussed in the literature. Mokhils (2009) explains that an exploration of the different definitions of religiosity reveals that there is inconsistency in its definition. This opinion was premised on the views of Clarke and Byrne (1993) who report the definition of religiosity is affected by the historical conceptualisation of religiosity, the ambiguous use of the concept and the relativity in the application by scholars to suit their purposes. Patel (2012) posits that religiosity is the degree to which an individual or persons are affiliated and committed to a religious group. In that same vein, Esso and Dibb (2004) stress that religiosity is the extent to which an individual adheres to certain beliefs and principles established by a supreme being. Abou-Youssef et al. (2015) argue that religiosity is a specific derivation of religion while Al Abdulrazak and Gbadamosi, (2017) opine that religiosity relates to values, experiences, beliefs and practices which influences the way an individual thinks, responds and expresses emotions in the activities of life. These definitions give room for a critical review since they are defined outside the place in which this study was carried out. In achieving the objective of this study, there is a need to define religiosity in the Nigerian context.

While the concept of religiosity could be a universal construct, its application could be country-specific (Mokhils, 2009). Somefun (2019) in explaining religiosity in the Nigerian context, posits that religiosity is a pivotal feature of religion which deals with the extent of religious belief and involvement. Halliru (2013) assets that religiosity is the framework which guides the activities, beliefs and spirituality of the average Nigerian in the process of carrying out activities. Endong (2016) observes that religiosity is the way of life of the Nigerian people, which can be seen in both their abstract and material life. These definitions provide significant background for this study. In essence, religiosity is the total involvement of a person in a set of beliefs, principles and practices which influence and guide the behaviour of such a person in expressing emotions. Nigeria is viewed as a secular state, not because it does not have different religious practices, but called so because no particular religion is supreme to another (Ogbu, 2014). The three main types of religion in Nigeria are Christianity, Islam and traditional religion. These religions are also characterised by different affiliations, denominations and beliefs which influence the way their followers react to issues. Al Abdulrazak and Gbadamosi (2017) are of the opinion that in the Nigerian context religiosity measurement differ among the three types of religions, and that measurement of religiosity is complex; the scale must include elements that are common to all of them. Abou-Youssef et al. (2015) posit that religious knowledge, religious orientation, religious commitment and religious affiliation are fundamental elements of religiosity which are common to all religions irrespective of the country of practice and people. Abu-Alhaija et al. (2018) argue that these measures are robust and are significant in explaining consumer behaviour. Thus, in ascertaining the effect of religiosity on customer experience in the hospitality industry in Nigeria, these measures, as proposed by Abou-Youssef et al., (2015), are adopted in this study.

\section{Customer Experience and Measurement}

Customer experience has become a significant factor in the competitiveness and success of a firm or an industry (Sharma \& Chaubey, 2014; Wei, Ang and Anaza, 2019). This is premised on the idea that superior and memorable customer experience has the capacity to enhance different performance measure in any industry. Pekovich and Rolland (2020) explain that firms that create a strong customer experience outperform firms whose customers do not get such a memorable experience. This means such firms attract better brand preference and can increase the prices of their product and services, thereby outperforming their rivals in both growth and stock price. McColl-Kennedy et al. (2019) see customer experience as a construct which is made up of discrete emotions, 
cognitive reactions and value creation elements (interactions and customer interaction, contextual roles and resource activities) which make the customer journey in the service encounter process an exciting one. Customers experience could be seen as an expression of the customers' emotions in the service encounter process (pre-purchase, service delivery and consumption stage). Pekovich and Rolland (2020) opine that customers experience depends on divergent factors which could be uncontrollable or difficult to manage by the firm and that such factors include the customers' preferences, personal characteristics and beliefs. Siqueira et al. (2020) suggest that customer experience model should be an integration of uncontrollable and controllable factors. Although the concept of customers experience has started gaining pre-eminence in existing literature, the issue of its measurement has become of a great concern Mahr, Stead, \& Odekerken-Schr€oder, 2019).

Molinillo et al. (2020) explain that the customer experience model should include affective and cognitive dimensions while $\mathrm{Pi}$ otrowicz and Cuthbertson (2014) suggest that the measurement should include technological dimension as this will enhance the customers in fully interacting with the firm while fostering a better relationship based on convenience. Klaus and Maklan (2013) in exploring the concept of customer experience proposed product experience, outcome focus, moments of truth and peace of mind as the right measurements of this construct. Keiningham et al. (2020) posit that the measurement of customer experience should be include social, emotional, sensory, physical and cognitive dimensions. They assert that such dimensions would help the firms to understand, interpret and take valuable managerial decisions which will enhance the firms' performance both in the long and short run. This view was supported by Pekovich and Rolland (2020) who report that since customer experience is a multidimensional construct it should be measured in terms of customer cognitive, emotional, social, sensorial and behavioural and technological experience in the service encounter process. In this study, the dimensions established by Pekovich and Rolland (2020) are adopted since they provide a robust explanation into the nature of customer experience (Keiningham et al., 2020 The cognitive experience deals with rational, conscious and thinking mental capability of the customer to evaluate a firm's product offering at the pre-purchase and purchase stage (Lemon and Verhof, 2016). According to Brun et al. (2017), the cognitive dimension has the capacity to improve customer commitment and loyalty. The emotional experience, on the other hand, reflects the perception of the customer, which is elicited after the consumption of a product or service. According to $\mathrm{Ou}$ and Verhoef (2017), the emotional dimension is a significant driver of customer behaviour. Oliver (1997) opines that this dimension significantly drives customers' preferences, evaluation, purchase intention and recommendations. Dube and Menon (2000) assert that emotional experience happens during consumption and that this provides the platform for customer loyalty.

The behavioural experience captures the customer engagement in the service offering and delivery process. Nysveen and Pedersen (2014) are of the view that the behavioural experience allows the customers to participate, co-produce, suggest, share new ideas and criticise the firm's product in order to have a better service journey. Ranjan and Read (2014) report that behavioural experience is a significant driver of customer satisfaction and loyalty. The sensory experience involves the functioning of the five human senses (Pekovich and Rolland, 2020). Vargo and Lusch (2004) opine that the human sensory organs are the major driver of customer attitude and judgement in interacting with the firms' product and services. Gentile et al. (2007) argue that the sensory experience is induced by the sensory perception of the service environment and atmosphere which incites excitement, aesthetic pleasure, satisfaction, and positive behavioural intentions in the customers.

The social experience involves the interaction between a customer and other customers who patronise a particular firm or its rival. Gentile et al. (2007) report that social experience is a function of social relationship and contexts which emerge during the customer service. The experience occurs when custom- 
ers interact with employees of a firm and other customers (Yi and Gong, 2008). However, most recently the study of Garg and Qureshi (2014) has revealed that frontline employees contribute majorly to the social experience regardless of their demographic distribution and status. According to Pekovich and Rolland (2020), the more the customers interact with a firm's technological platform, the more the technological experience that is aroused in the customer. Bolton et al. (2018) stress that the integration of emotional, sensory, cognitive, behavioural, social and technological experiences creates the optimal customer experience.

\section{Religiosity and Customer Experience in the Hospitality Industry: the Nexus}

Recently, there has been increasing awareness and the recognition of the impact of religiosity on the customer behaviour (Argawala et al., 2018; Mathras et al., 2016). Most studies on religiosity and consumer behaviour have been streamlined to market segmentation. For instance, Ahmad, Rustam, \& Dent, 2011; Alserhan, 2010, argue that there should be a separate market for Muslims as it regards the consumption of pork product due to their religious affiliations. Mathra et al. (2016) suggest that Christians exhibit more of social experience and sensory experience than other religions while the Muslims are biased towards haram (prohibition) and halal (permissible) of agricultural products. Sibal (2018) points out that religions prescribe the type of food their followers must consume, although such dietary instruction varies among people of the same religion. This could be as a result of denominations, religiosity and individual belief. Mokhlis (2009) reveals that there is no significant difference among Christians, Muslims and other religious faiths in terms of their shopping pattern. However, religiosity could lead to consumers exhibiting greater price consciousness, lower impulsive buying habit regardless of their demography. Farah and Samad (2014) posit that customers with high religiosity are more matured, responsible and disciplined in their purchases' orientation which makes them make rational decisions. Alam et al. (2001) opine that Muslim custom- ers exhibit higher religiosity than other religions because they take the Islamic dictates as the reference points when making decisions relating to food. Esso and Dibb (2004) are of the view that customers with high religiosity consider some products offensive while customers with low religiosity are indifferent about any product or service. Halliru (2013) indicates that religiosity affects the Nigerian population consumption behaviour and has the capacity to determine their preference for food, protein, beverage and type of clothing. According to Mathras et al. (2016), most of the studies undertaken in religion and consumer research have been qualitative, and this creates a need to investigate the interaction between religiosity and consumer behaviour. In addition, they also stress that studies on the impact of religion on consumer behaviour are scanty and this creates the need to develop a theoretical framework and empirical studies which will reveal the true extent to which religiosity affects customer psychology. Premised on the discussions, this study proposes the following hypotheses:

$\mathrm{H}_{\mathrm{A}}$ 1: Religiosity significantly affects customer experience in the hospitality industry

$\mathrm{H}_{\mathrm{A}}$ 2: There is no significant difference among the three religious groups as it relates to the customer experience.

\section{Theoretical Review}

\section{Consumer Culture Theory (CCT)}

The consumer culture theory is a theory which is premised on the belief that there is a socio-cultural aspect to consumers psychology. According to Amould (1989), CCT provides insight into understanding the real behaviour of the customers. The theory explains the interaction between exchange and consumption. Arnould (2001) and Thompson explain that the CCT as a field of enquiry reveals the complexities in the consumer culture in which religion is a sub-component. Armould et al. (2019) argue that the CCT reflects what the customer believes in and what transcends from such belief rather than who the customer is. From the standpoint of the CCT, the consumer religion is a dynamic and symbolic network which determines the level of social interaction. Arnould and Cayla 
(2015) emphasise that the consumer culture which integrates religiosity is key in explaining the customer live experiences, socio-economic engagement and how resources have been expended. Arnould et al. (2019) report that the customers' perception of what quality is, what induces desire and how their emotion is being expressed is central and symbolic to the consumer culture. The CCT also conceptualises the interrelated system of consumption and culture, which produces emotions, experiences, images, text and continuously reveals the evolving emotions of the consumer society. This theory was adopted in this study because it recognises that the consumer experience is always influenced by historical and subsocial, cultural behaviour (Arnould, 2001).

\section{Methodology}

The descriptive survey research was utilized in this study. The study was carried out in Osun State in Nigeria, which has a population of 4.7 million people. The choice of Osun state was influenced by the fact that it has the presence of prominent tourist attractions such as the Osun-Osogbo Sacred Grove, Nike Art Gallery Olumirin, Osun festival, Botanical Gardens, National Museums and Waterfall. The total number of tourists that visits Osun state on the average is 121,000 annually (Idowu, 2018). A multistage sampling technique was employed. The study adopts the smallholder household survey in Nigeria, which is a nationally accepted representative of the Nigerian population, the target sample size for this study stands at 3,000 respondents (Anderson et al., 2017). The respondents are individuals above 18 years of age who have visited the tourist places. Using the raosoft sample estimator at $99 \%$ confidence level and $5 \%$ margin of error, the total surveyed sample size is 544 . This represents the total number of customers surveyed. A well-structured questionnaire comprising of 20 measured items for religiosity grouped into religious knowledge, religious orientation, religious commitment and religious affiliation was adopted from the study of Abou-Youssef et al., (2015) while 24 items measures grouped into emotional, behavioural, sensory, social, technological and cognitive experience were adopted from the study of Pekovich and Rolland (2020) were adopted. The questionnaires were distributed equally among the three main religions (Christianity, Islam and traditional religion) respondents. The research instrument was self-administered with the aid of trained research assistants to the respondents. The questionnaire administered was designed in a seven Likert scale instrument ranging from 1 (least agreed) to 7 (most agreed). 425questionnaires were properly filled and returned for analysis. This represented about $78 \%$ and was considered sufficient for analysis based on the recommendations of Hair et al. (2014). The partial least square - structural equation model was employed in the analysis of the result.

\section{Reliability and Validity of Research Instrument}

Face and construct validity were ensured in the study. The research instrument was tested by independent evaluators who are expert in the field of religion and business administration and marketing in establishing the face validity of the research instrument. The confirmatory factor analysis (CFA) was employed in ensuring the construct validity on each item in the research. The test-retest method was applied by administering the research instrument twice on a selected set of respondents at different times. The result of the first and second pilot tests was correlated. A Cronbach alpha of $\alpha=0.843$, $0.764,0.788,0.762,0.861,0.769,0.855,0.791$, 0.844 and 0.768 was obtained for religious knowledge, religious orientation, religious commitment, religious affiliation, emotional, behavioural, sensory, social, technological and cognitive experience According to (Muhamad \& Mizerski, 2010, Nysveen, et al., 2013, Oliver, 1997), these results are highly acceptable. The study utilises the partial least squares structural equation model (PLS-SEM) in explaining the interactions and strength of path and evaluates how best the models fit the data. It makes it possible for the estimation of the cause-effect relationship between the latent variables. The confirmatory factor analysis will enhance the testing of a' prior model of the measured variables. The SMART PLS 3 statistical tool is used in the analysis of data. 


\section{Model Specification}

The theory underpinning the model for this study is customer culture theory based on the study of Abou-Youssef et al., (2015) which employed religiosity as a direct antecedent of customer behaviour. The model can be expressed as follows

$$
\begin{aligned}
& \mathrm{CX}=\beta 0+\beta 1 \text { (Religiosity) } \\
& \mathrm{CX}=\beta_{0}+\beta_{1}(\mathrm{RN})+\beta 2(\mathrm{RO})+\beta 3(\mathrm{RC})+ \\
& +\beta 4(\mathrm{RA})+\mu
\end{aligned}
$$

$\mathrm{CX}=$ emotional, behavioural, sensory, social, technological and cognitive experience

where

$\mathrm{RN}=$ Religious Knowledge

RO: Religious Orientation

$\mathrm{RC}=$ Religious Commitment

$\mathrm{RA}=$ Religious Affiliation

CX: Customer Experience

The psychometric properties of the scale in Table 1 were assessed employing the Confirmatory Factor Analysis (CFA). All variables were tested in the model, and items load were restricted to the criteria established by Fornell and Larcker's (1981). That is, the ability to measure the latent variables and internal consistency of the scale was $>0.5$. The results show a high sign of average variance and construct reliability for all latent variables. The content and construct validity were ensured. In achiev- ing face validity, the researchers ensured that the instrument measure what it was intended to measure, by adopting the instrument used by previous studies while the CFA was utilised to ensure construct validity.

\section{Descriptive Analysis}

Figure 1 shows the perception of the three religions in Nigeria. In terms of emotional experience, the graph reveals that the Christians (80\%) have better emotional experience than the other religious sects while the Muslims show least expressions during service encounter in the hospitality sector. In the analysis of the sensory experience, the results reveal that the traditional $(80 \%)$ believes that the environment and atmosphere incite excitement, aesthetic pleasure, satisfaction, and positive intentions in them than the Muslims (78\%) and Christians $(65 \%)$. This refutes the claim of Mathra et al. (2016), who explains that the Christians exhibit more sensory experience than other religions.

The behavioural experience also shows that the traditional worshippers $(82 \%)$ co-produce, suggest, share new ideas and criticise the firms' product in order to have a better service journey than the Muslims (76\%) and the Christians $(72 \%)$. In terms of cognitive experience, the Christians ( $80 \%$ ) are more rational, conscious and thinking mental capability of the

Table 1. Psychometric Properties of the Scale

\begin{tabular}{lcc}
\hline \multicolumn{1}{c}{ Measurement } & Cronbach Alpha $\alpha$ & Average Variance Extracted \\
\hline Religiosity & 0.874 & 0.712 \\
Religious Knowledge & 0.843 & 0.699 \\
Religious Orientation & 0.764 & 0.641 \\
Religious Commitment & 0.788 & 0.676 \\
Religious Affiliation & 0.762 & 0.631 \\
\hline Customer Experience & 0.878 & 0.781 \\
Emotional & 0.861 & 0.722 \\
Sensory & 0.855 & 0.739 \\
Behavioural & 0.769 & 0.669 \\
Social & 0.791 & 0.688 \\
Cognitive & 0.768 & 0.684 \\
Technological & 0.844 & 0.756 \\
\hline
\end{tabular}

Source: Author's Analysis. 


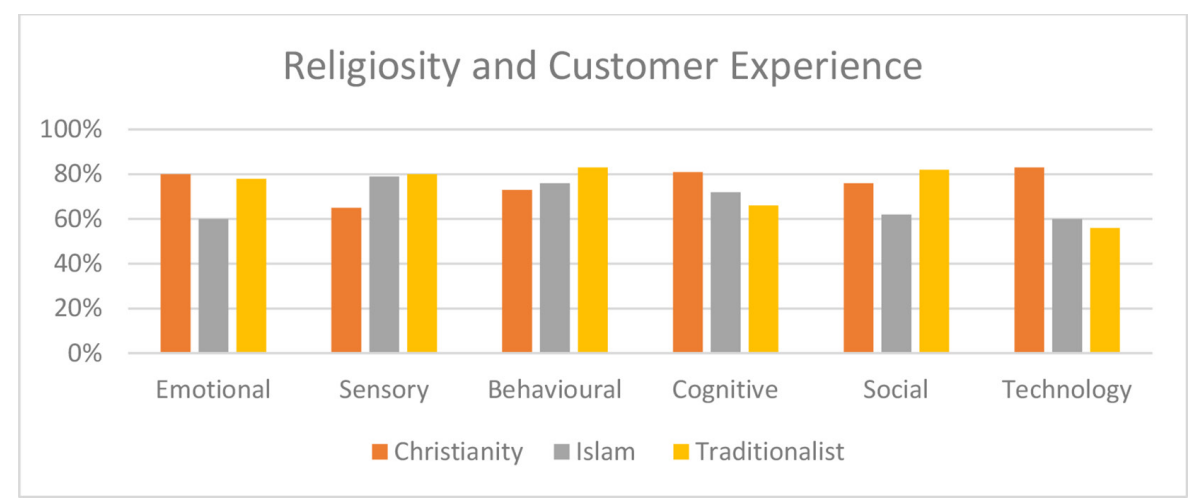

Fig. 1. Religiosity and Customer Experience

customer to evaluate a firm's product offering at the pre-purchase and purchase stage than the Muslims (72\%) and the traditionalists (68\%). The graph shows that the traditional worshippers $(82 \%)$ have better social experience by interacting more with the other customers and the firm than the Christians (78\%) and the Muslims (62\%). This negates the opinion of Mathra et al., who explains that the Christians exhibit more social experience than other religions. In the technological experience analysis, the result reveals that the Christians ( $82 \%$ ) have better technological experience than the other religions.

\section{Results and discussions}

The result from Table 2 reveals that there is a positive and significant relationship ( $\beta=0.911)$ between religiosity and customer experience. The coefficient of determination $(\mathrm{R} 2=0.978)$ reveals that $97.8 \%$ variation in customer experience is explained by religios- ity. The standard error $(\mathrm{SE}=0.007)$ indicates that the model is a good fit by revealing how religiosity predicts customer experience since the value falls between the accepted estimates. This also indicates that religiosity is a driver of the customer experience. The unstandardised coefficient $(\mathrm{B}=0.985)$ shows that for every unit increase in religiosity customer experience increases by 0.0 .985 units. The t-value $(\mathrm{t}$-value $=134.688, \mathrm{p}=0.000)$ establishes that religiosity is a significant predictor of customer experience.

\section{Path Analysis Showing the Interaction Between the Dimensions of Religiosity and Customer Experience}

Figure 2 shows the error variance and all the freely estimated paths between loyalty programmes and customer experience. The structural equation model achieved a goodness fit $(\chi 2=749.32, \mathrm{df}=156, \mathrm{p}=0.00 ; \mathrm{GFI}=0.99$, RMSEA $=0.090, \mathrm{IFI}=0.95, \mathrm{CFI}=0.97)$. The

Table 2. H1: Religiosity significantly affects customer experience

\begin{tabular}{|c|c|c|c|c|c|}
\hline & \multicolumn{4}{|c|}{ Customer Experience } & \\
\hline Variable & B & SE & $\beta$ & T-Value & P-Value \\
\hline Religiosity & 0.985 & 0.007 & 0.989 & $134.668 x^{\prime}$ & 0.000 \\
\hline $\operatorname{Adj} R^{2}$ & 0.978 & & & & \\
\hline F-Stat & $\begin{array}{c}43.480 \\
(p=0.000)\end{array}$ & & & & \\
\hline Collinearity & 1.240 & & & & \\
\hline
\end{tabular}

Source: Author's Computation (2020). 


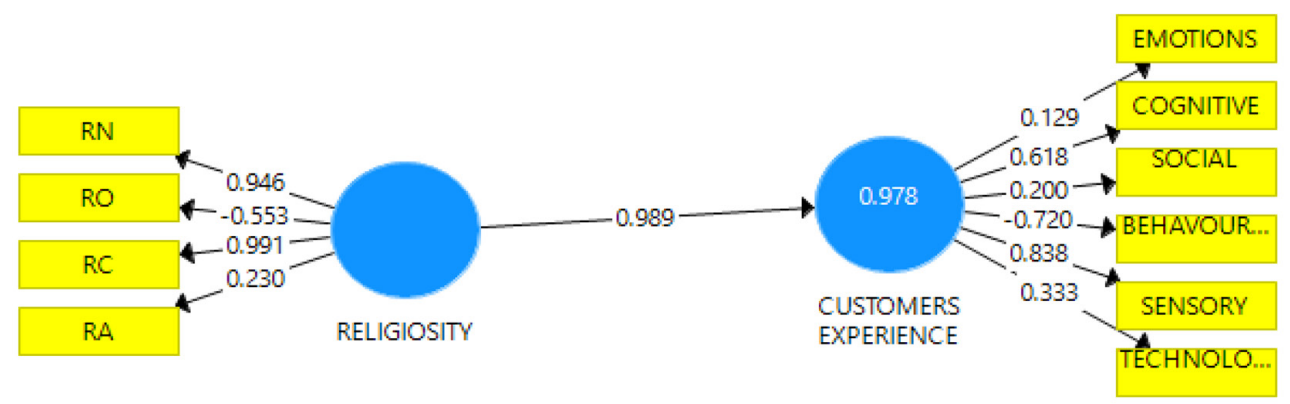

Fig. 2. The Interaction between Religiosity and Customer Experience. Source: Author's Conceptualisation

path analysis reveals the effect of religiosity on customer experience. The findings reveal that religious knowledge $(\beta=0.946)$ is the most significant observed measure of religiosity affecting customer experience among smallholder households in hospitality. The path analysis also reveals that sensory experience $(\beta=0.838$ is the most significant construct of customer experience influenced by religiosity.

\section{Hypothesis 2}

Table 3 shows that in analysing the effect of religiosity on customer experience in each type of religion, there is no significant difference. The result reveals that religiosity is not statistically significant in all three main types of religions in Nigeria. Christianity (Mean-Between Groups = 2.289, Mean-With- in Groups $=2.289, \mathrm{~F}-\mathrm{Stat}=1.210, \mathrm{p}=0.306)$, Islam (Mean-Between Groups $=0.968$, Mean-Within Groups $=1.762$, F-Stat $=0.550$, $\mathrm{p}=0.649$ ) and traditionalist (Mean-Between Groups $=1.124$, Mean-Within Groups $=2.491$, F-Stat $=0.451, p=0.717)$ indicates that there is no significant relationship between religiosity and customer experience in each of the religions. The $\mathrm{F}$-value reveals that shows that Christianity $(\mathrm{F}-\mathrm{Stat}=1.210, \mathrm{p}=0.306)$, Islam $(\mathrm{F}-\mathrm{Stat}=0.550, \mathrm{p}=0.649)$ and traditionalist $(\mathrm{F}-\mathrm{Stat}=0.451, \mathrm{p}=0.717)$ is not a good fit in explaining how precisely religiosity affects customer experience among the three religions.

\section{Discussion of results}

From the descriptive analysis, the results indicate that the three main types of religion in

Table 3. There is no significant difference among the three religious groups as it relates to the customer experience

\begin{tabular}{|c|c|c|c|c|c|c|}
\hline & & Sum of Squares & $d f$ & Mean Square & $\mathrm{F}$ & Sig. \\
\hline \multirow[t]{3}{*}{ Christianty } & Between Groups & 6.867 & 3 & 2.289 & 1.210 & .306 \\
\hline & Within Groups & 796.395 & 421 & 1.892 & & \\
\hline & Total & 803.261 & 424 & & & \\
\hline \multirow[t]{3}{*}{ Islam } & Between Groups & 2.905 & 3 & .968 & .550 & .649 \\
\hline & Within Groups & 741.815 & 421 & 1.762 & & \\
\hline & Total & 744.720 & 424 & & & \\
\hline \multirow[t]{3}{*}{ Traditionalists } & Between Groups & 3.371 & 3 & 1.124 & .451 & .717 \\
\hline & Within Groups & 1048.667 & 421 & 2.491 & & \\
\hline & Total & 1052.038 & 424 & & & \\
\hline
\end{tabular}


Nigeria exhibit customer experience in various degrees and dimensions. The study shows customer experience happens in various degrees among people of different religions and affiliations. The findings corroborate the position of Mathral et al., (2016) and Esso and Dibb (2014) who argue that customers behaviour across different religions varies. Hypothesis 1 shows that religiosity is an important driver of customer experience among smallholders' households. It can be inferred that firms should look at the religious commitment, knowledge, affiliation and orientation of the customers in the process of product offering and service delivery. The result also indicates that religious knowledge and orientation are the most critical components of religiosity that affect customer experience and that sensory experience and behavioural experience are pivotal to religiosity. The result of the analysis confirms the argument by Al Abdulrazak, Gbadamosi (2017) and Patel (2012) who are of the view that religiosity is a determinant of customer behaviour. While existing literature shows more concern about the customer behaviour, this study establishes that religiosity significantly affects customer experience, which is a specific expression of customer behaviour. Hypothesis 2 shows that while there is a difference in customer experiences among the three main religions in the hospitality industry, such difference is not significant. The dimension of religious affiliation is the least significant measure of religiosity. This implies that firms should not be much concerned about the affiliation of the customers; rather, they should be concerned about the type of religion the customers belong to. The analysis reveals that the opinion of the customers is based on the type of religion they practice and not the affiliation they belong to. The Christians have a better experience than other religions sect. Although the result shows this, in the final analysis, it is revealed that there is no significant difference in how every religion feels. The study confirms the opinion of Mohkils (2009) and Muhamad, N., Mizerski, D., 2010, who establish that there is no significant difference in the expression of emotions among religious sects in their consumption of goods and service.

\section{Practical Implication}

The role and significance of religion as relating to religious affiliation, commitment, orientation and knowledge of the customers should not be ignored by firms in the provision of goods and services. Firms should strive to provide a pre-purchase, during purchase and after-sales service experience, which will lead to a positive feeling and expression of emotions in their customers. This has the capacity to increase patronage, loyalty and make the firm achieve competitiveness both in the long and in the short run.

\section{Conclusion}

The study establishes that religiosity is a significant driver of customer experience in the hospitality sector. Understanding the customers' religious affiliation, commitment, orientation, and knowledge are key to offering and providing services which have the capacity to bring about positive feeling and creating an optimal experience in the customers. Firms should pay more attention to customers' religious orientation and knowledge; this will increase the firms' potential to tailor their product and services towards meeting the specific needs of the customers and creating a new and exciting experience. The study also concludes that in the firm should be more concerned about the customer sensory, behavioural and cognitive experience since these are the most critical measures of the customer experience. Based on the findings from this study, it is recommended that firms should pay attention to the religion of the environment in which they exist in order to give the customers an exciting experience. More attention should be paid to the customer religious orientation and knowledge.

\section{Research Limitations}

The study was carried out in the hospitality industry alone. There is a need to examine the impact of religiosity in other industries in order to document the full extent of the influence of religiosity. Future studies should also develop various dimensions which will fully capture the religious atmosphere in the specific environment. 


\section{References}

Abdullah, K., \& Ahmad, M. (2010). Compliance to Islamic marketing practices among businesses in Malaysia. In Journal of Islamic Marketing, 1 (3): 286-297.

Abou-Youssef, M.M.H., Kortam W., Abou-Aish E., and El-Bassiouny N. (2015). Effects of Religiosity on Consumer Attitudes toward Islamic Banking in Egypt. In International Journal of Bank Marketing, 33 (6): 786-807. DOI:10.1108/IJBM-02-2015-0024.

Abu-Alhaija, A., Yusof, R., Hashim, H. \& Jaharuddin (2018). Religion in consumer behaviour research: The significance of religious commitment and religious affiliation. In International Journal of Economics, Commerce and Management, 245-259.

Agarwala, R., Mishra, P. \& Singh, R. (2018). Religiosity and consumer behaviour: a summarizing review. In Journal of Management, Spirituality \& Religion, DOI: 10.1080/14766086.2018.1495098.

Ahmad, K., Rustam, G.A., \& Dent, M.M. (2011). Brand preference in Islamic banking. In Journal of Islamic Marketing, 2(1), 74-82.

Al Abdulrazak, R.M., \& Gbadamosi, A. (2017). Trust, religiosity, and relationship marketing: a conceptual overview of consumer brand loyalty. In Society and Business Review, 12(3), 320-339.

Alam, A., Arshad, M.U., \& Shabbir, S.A. (2012). Brand credibility, customer loyalty and the role of eligious orientation. In Asia Pacific Journal of Marketing and Logistics, 24(4), 583-598.

Alserhan, B.A. (2010). On Islamic branding: Brands as good deeds. In Journal of Islamic Marketing, 1(2), 101-106.

Anderson, J., Marita, C., Musiime, D. \& Thiam, M. (2017). National Survey and Segmentation of Smallholder Households in Nigeria: Understanding Their Demand for Financial, Agricultural, and Digital Solutions. CGAP Working Paper, 1-93.

Arnould, E.J. (1989). Toward a Broadened Theory of Preference Formation and the Diffusion of Innovations: Cases from Zinder Province, Niger Republic. In Journal of Consumer Research, 16(September): 239-267.

Arnould, E.J. (2001). Ethnography, Export Marketing Policy, and Economic Development in Niger. In Journal of Public Policy and Marketing, 20, 151-69.

Arnould, E.J. and Cayla J. (2015). Consumer Fetish: Commercial Ethnography and the Sovereign Consumer. In Organization Studies, 36(10): 1361-1386.

Arnould, E.J., Press, M., Salminen, E. \& Jack S. (2019). Consumer Culture Theory: Development, Critique, Application and Prospects. In Foundations and Trends in Marketing, 12(2) 80-165.

Bolton, R.N., McColl-Kennedy, J.R., Cheung, L., Gallan, A., Orsingher, C., Witell, L., Zaki, M. (2018). Customer experience challenges: bringing together digital, physical and social realms. Journal of Service Management, 29, 776-808.

Brun, I., Lova, R., Ricard, L., Bilitis, B. (2017). Impact of customer experience on loyalty: A multichannel examination. In Journal of Service Industry, 37, 317-340.

Clarke, P.B. \& Byrne, P. (1993). Religion defined and explained. London: MacMillan Press Ltd.

Esso, N. \& Dibb. S. (2004). Religious influences on shopping behaviour: An exploratory study. In Journal of Marketing Management, 20 (7-8): 683-712.

Farah, M.F. \& Samad, L. (2014). The Effects of Religion and Religiosity on Advertisement Assessment among Lebanese Consumers. In Journal of International Consumer Marketing, 26:4, 344-369.

Garg, R.R., Qureshi, M.N. (2014). Measuring customer experience in banks: scale development and validation. In Journal of Modelling Management, 9, 87-117.

Gentile, C., Spiller, N., Noci, G. (2007). How to sustain the customer experience: an overview of experience components that co-create value with the customer. In European Journal of Management, 25 (5), $395-410$.

Hair J.F., Anderson R.E., Tatham B.B. \& Black W.C. (2010). Multivariate Data Analysis (7th Edition) 7th Edition. Pearson Ltd.

Halliru, M. (2013). Culture and Values in Consumer Behaviour: The Nigerian Experience. In International Journal of Arts and Commerce, 2 (10), 103-114. 
Idowu, O. (2018). Osun-Osogbo Grove receives 121,000 visitors at annual festival. Available at: https:// cityvoiceng.com/osun-osogbo-grove-receives-121000-visitors-at-annual-festival-curator/

Keininghama, T., Aksoyb, L., Brucec, H.L., Cadeta, F., Clennelld, N., Hodgkinsone, I.R., Kearneyf, T. (2020). Customer experience-driven business model innovation. In Journal of Business Research. Available at: https://doi.org/10.1016/j.jbusres.2019.08.003.

Klaus, P., Maklan, S. (2013). Towards a better measure of customer experience. In Int. Journal of Marketing Research, 55 (2), 227-246.

Kuppelwiesera, V.G. \& Klaus, P. (2020). Measuring customer experience quality: The EXQ scale revisited. In Journal of Business Research. Available at: https://doi.org/10.1016/j.jbusres.2020.01.042

Lemon, K.N., Verhoef, P.C. (2016). Understanding customer experience throughout the customer journey. In Journal of Marketing, 80 (6), 69-96.

Mahr, D., Stead, S., Odekerken-Schr€oder, G. (2019). Making sense of customer service experiences: a text mining review. In Journal of Service and Marketing, 33, 88-103.

Mathras, D., Cohen, A.B., Mandel, N. \& Mick, D.G. (2015). The Effects of Religion on Consumer Behavior: A Conceptual Framework and Research Agenda. In Journal of Consumer Psychology, 1-27.

McColl-Kennedy, J., Zaki, M., Lemon, K., Urmetzer, F., Neely (2019). Gaining customer experience insights that matter. In Journal of Service and Reports, 22, 8-26.

Mokhlis, S. (2009). Relevancy and measurement of religiosity in consumer behaviour research. In International Business Research, 2 (3): 75-84.

Molinillo, S., Navarro-García, A., Anaya-Sanchez, R., Japutra, A. (2020). The impact of affective and cognitive app experiences on loyalty towards retailers. In Journal of Retailing and Consumer Service. Available at: https://doi.org/10.1016/j.jretconser.2019.101948

Muhamad, N., \& Mizerski, D. (2010). The constructs mediating religions' influence on buyers and consumers. In Journal of Islamic Marketing, 1(2), 124-135.

Nysveen, H., Pedersen, P.E., Skard, S. (2013). Brand experiences in service organizations: Exploring the individual effects of brand experience dimensions. In Journal of Brand Management, 20, 404-423.

Oliver, R.L. (1997). Satisfaction: A Behavioral Perspective on the Consumer. McGraw-Hill, New York.

Ou, Y.C., Verhoef, P.C. (2017). The impact of positive and negative emotions on loyalty intentions and their interactions with customer equity drivers. In Journal of Business Research, 80, 106-115.

Patel, M. (2012). Influence of religion on the shopping behaviour of consumers: An exploratory study. In Abhinav National Monthly Refereed Journal of Research in Commerce \& Management, 1 (5): 68-78.

Pekovic, S. \& Rolland, S. (2020). Recipes for achieving customer loyalty: A qualitative comparative analysis of the dimensions of customer experience. In Journal of Retailing and Consumer Services, 1-15.

Ranjan, K.R., Read, S. (2014). Value co-creation: concept and measurement. In Journal of Academic and Marketing Science, 44 (3), 290-315.

Siqueira, J.R., Horst, E., Molina, G., Losada, M., Mateu, M.A. (2020). A Bayesian examination of the relationship between internal and external touchpoints in the customer experience process across various service environments. In Journal of Retailing Consumerism and Service.

Sibal, V. (2018). Food: Identity of Culture and Religion. Available at: https://www.researchgate.net/ publication/327621871

Sharma, M. \& Chaubey, D.S. (2014). An empirical study of customer experience and its relationship with customer satisfaction towards the services of banking sector. In Journal of Marketing and Communication, 9, 18-27.

Stein, A., Ramaseshan, B. (2016). Towards the identification of customer experience touchpoint elements. In J. Retailing Consum, Serv. 30, 8-19.

Vargo, S.L., Lusch, R.F. (2004). Evolving to a new dominant logic for marketing. In Journal of Marketing, 68 (1), 1-17.

Wei, S., Ang, T., Anaza, N.A. (2019). The power of information on customers' social withdrawal and citizenship behaviour in a crowded service environment. In Journal of Service and Management, 30, 23-47. 
Yi, Y., Gong, T. (2008). If employees go the extra mile, do customers reciprocate with similar behaviour? In Psychology Marketing, 25, 961-986.

\title{
Религиозность и качество обслуживания клиентов: на примере сферы гостеприимства в Нигерии
}

\author{
П.М. Уоримегбе \\ Университет Олабиси Онабанджо \\ Нигерия, Огун, Аго-Айвой
}

\begin{abstract}
Аннотация. В существующей литературе представлены спорные мнения о влиянии религиозности на качество обслуживания клиентов. В данном исследовании рассматривается влияние религиозности на качество обслуживания клиентов, представляющих три основные религиозные группы в секторе гостеприимства в Нигерии. Исследование основано на аспектах религиозности, которые включают в себя религиозное знание, ориентацию, приверженность и принадлежность. В исследовании приняли участие 544 клиента из отрасли гостеприимства, которые представляли три основные религии в Нигерии. Для анализа данных применялся PLS-SEM.

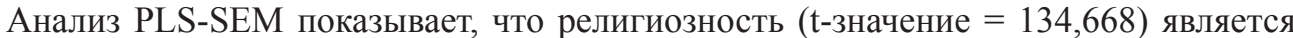
существенным фактором, определяющим уровень удовлетворенности качеством обслуживания клиентов в секторе гостеприимства. Результаты также показывают, что между тремя основными этническими группами в Нигерии нет значительных различий в восприятии клиентами качества обслуживания. Исследование выявило, что компаниям необходимо обращать внимание на религиозность, чтобы уровень удовлетворенности клиентов качеством обслуживания был высоким. Больше внимания следует уделять религиозной ориентации и знаниям клиентов. Фирмы не должны игнорировать роль и значение религии для клиентов при предоставлении товаров и услуг, что приведет к улучшению качества обслуживания.
\end{abstract}

Ключевые слова: гостеприимство, религиозность, качество обслуживания клиентов, предоставление услуг.

Научная специальность: 08.00.00 - экономические науки. 